\title{
Syphilis - not just a STI
}

\author{
Victoria Robinson \\ From Society of Chiropodists and Podiatrists Annual Conference 2010 \\ Bournemouth, UK. 21-23 October 2010
}

Syphilis has increased tenfold over the past decade, information for podiatrists that emphasizes it implications and relation to the lower limb is limited. The aim of the poster presentation is to draw attention to syphilis and is relevance within the $20^{\text {th }}$ century.

A literature review inspired the production of the poster. The purpose of the poster is to inform other podiatrists about the various signs, stages. symptoms and manifestations of syphilis. The poster covers many aspects which are relevant to the profession; it highlights the neurological, dermatological and wound presentations, as well as the subsequent management and diagnosis.

The poster has been designed to inform peers, with the aim to bring syphilis and its complications to the forefront with regards to the recent increase in the condition thus highlighting its relevance to the lower limb and podiatry.

Published: 20 December 2010

doi:10.1186/1757-1146-3-S1-P16

Cite this article as: Robinson: Syphilis - not just a STI. Journal of Foot

and Ankle Research 2010 3(Suppl 1):P16.

Durham School of Podiatric Medicine, Durham, UK

Submit your next manuscript to BioMed Central and take full advantage of:

- Convenient online submission

- Thorough peer review

- No space constraints or color figure charges

- Immediate publication on acceptance

- Inclusion in PubMed, CAS, Scopus and Google Scholar

- Research which is freely available for redistribution 